RESEARCH PAPER

\title{
Perception of Dowry: Effects on Women Rights in Punjab
}

\author{
1Dr. Bushra Yasmeen $\quad{ }^{2}$ Dr. Muhammad Ramzan ${ }^{3}$ Dr. Asma Seemi Malik*
}

1. Former Chairperson/Associate Professor, Lahore Leads University, Lahore, Punjab, Pakistan

2. Assistant Professor, Institute of Social and Cultural Studies, University of the Punjab, Lahore, Pakistan

3. Assistant Professor, Department of Sociology, Lahore College for Women University, Lahore, Punjab, Pakistan

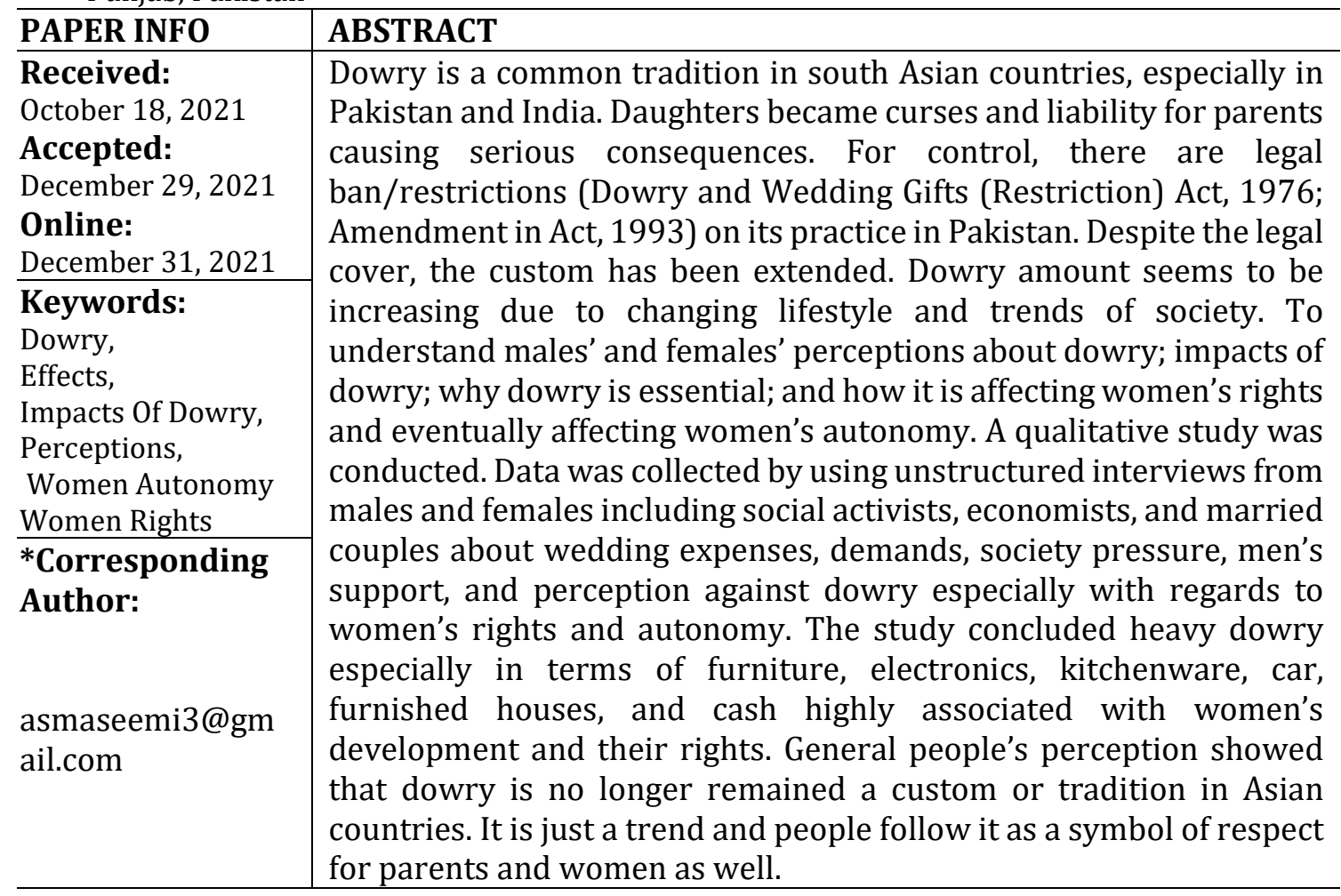

Introduction

Dowry is a common traditional practice in the South Asian region, mostly in Pakistan and India. It is considered as an economic liability more than a custom. Debates on women's rights seem to be merely false progressiveness or pseudo-modernization, affecting the process of women's development. The devaluation of women's gender is the result of a persistent loss of power and lack of developments in society affects the development process. In a patriarchal society, women are limited to the household, and norms suppress the autonomy of women from birth. From a cultural perspective, among the societal norms, the most common observing practice is Dowry. Gender imbalance starts from the birth of the child where a male child is considered more valuable and groomed accordingly due to the societal image of "Male as Assets" whereas female children are 
considered as a liability because of dowry. This can create a great imbalance between both genders mainly affecting women.

Today educated women are playing pivotal roles economically and socially in their families moving towards excellence and optimism, eliminating poverty and domestic issues (Manuela, 2016). Issues like violence against women, divorces, separations, suicides, and murders due to dowry indicate multiple reasons such as poverty, less education of males, ways of thinking, ignorance of the law, implementation of protection laws, moral values, traditions, etc., (Ali et al., 2013). Domestic violence awareness (2009) website on domestic violence indicates that India claims that since 2006, more than 123,497 women, most of them mother-in-law, have been arrested for alleged dowry-related killings. Such a situation creates a lack of security, importance, value, and confidence among women (Ali et al., 2007; Narayan, 1997). Therefore, the study was conducted to explore the perception of dowry in society; the effects of dowry on women's rights; and dowry effects on women's social and economic life.

Marriage assumes a significant part and defining moment of human life. Dowry is considered an umbrella or protective shield for married women. Among the cultural afflictions that win and tainting Pakistani society, the dowry framework assumes the significant one. It is rambling particularly pervasive in Pakistani culture (Shazia et al., 2012; Makino. 2014). Endless young women in Pakistan remain unmarried because their folks can't fulfill their needs (Anderson, 2007; Diamond-Smith, Luke, \& Mcgarvey, 2008; Garger, 2007; Rao, 1993). The presence of (net) dowry has been deciphered those women pay for marriage (Tertilt, 2005; Anderson, 2000). The "dowry" animosity doesn't give straightforwardly to marriage-related consumptions made at the hour of the pre-marriage ceremony, however to advantageous installments requested after the marriage by the lucky man's family where the spouse consistently manhandles the wife to coerce bigger exchanges (Bloch, 2002; Anderson, 2000). The dowry system, giving money and kindness from the lady of the hour's family to the lucky man or lucky man's family at the hour of marriage, has a long history in India and other Asian social orders (Lee, 1982). The act of dowry was normal in Europe, East Asia, South Asia, and the pockets of the Americas. Even though the custom has generally vanished in the western world, it existed in South Asia (Anderson, 2001).

\section{Dowry Practices in Pakistan}

The dowry system is an incredible fiendish that exists in Pakistan. It is a demonstration of oppression of unmarried young ladies, whose qualities are characterized dependent on the costs of their particular endowments. It is a case of covetousness and childishness and is an extraordinary revile, particularly for the parents who have a place with the lower working class. This is the motivation behind why people get discouraged and feel reviled at the introduction of a little girl. The dowry system ought to be prohibited in Pakistan, much the same as the serving of more than one dish at a marriage function. Restricting this convention prompts a more joyful life since it is a major wellspring of worry among parents of young girls - an Islamic demonstration (Shazia et al., 2012). Under the special marriage act 1872, a marriage custom indicates that there was no provision for giving dowry. Later on, it was restricted by social conviction. Under Islamic Law, Muslim women have respect, honor, protection, and given property rights (Niaz, 2003). Islam has never confined women's education, training, strengthening, or opportunity (Sheik, 2005). 


\section{Dowry Deaths}

Dowry death is considered as one of the many categories of violence against women, alongside rape, bride burning. A study by Nasrullah (2010) reports total average annual stove burn rates of 33 per 100,000 women in Pakistan, of which $49 \%$ were intentional, or an average annual rate of about 16 per 100,000 women (Miller, 1984; Terzieff, 2002). In Pakistan, 2,000 dowry deaths were reported per year. The highest death rate of dowry is at 2.45 per 100,000 women (Subhani et al., 2009; Anderson \& Siwan, 2000).

\section{Institution of Dowry in Islam}

Islam eradicated this evil in such an efficient way that even the non-Muslim nations were obliged to adopt the teachings of Islam on the subject. A lot of misunderstanding exists about the concept of dowry in Islam. Usually, a lavish dowry is termed as un-Islamic while an ordinary one is c considered a legitimate part of an Islamic marriage. The dowry and the bridal act are also based on this misunderstanding. In Islam, the responsibility for bearing all the expenses of marriage rests on the shoulders of the bridegroom. If the groom is in the position to meet this expenditure, well and good, otherwise he should refrain from marrying till he can arrange the dower money. Mehr required for the meeting the expenses of the marriages. (The Holy Quran) "And let those who cannot afford marriage, observe continence until Allah provides them with such mean."

Many hadiths of the Holy Prophet (God bless him and grant him peace) refer to this injection. In one of them, it is said that he said: Whoever finds a way to get married must do so, for this preserves the purity of sight. All of Jude's great Islamists have a similar view in this regard and demand that the person who seeks marriage first arrange the dowry money by earning honestly. The purpose of this Islamic injection is to make the husband a responsible member of the Muslim community so that he can lead an independent and respectful life. The Holy Quran says, "And give women to their dowries as a gift. But if they are themselves being pleased to give a portion thereof, consume it with enjoyment and pleasure."... "and if u wish to have (one) wife in the place of another and you have given one of them a heap of gold. Take nothing from it. Would you take it by slandering him and (doing her) manifest wrong?"

The marriage solemnized by the Holy Prophet (PBUH) is considered the model marriage in Islam and these were celebrated strictly according to the teaching of Islam. All his daughters, except Hazrat Fatima, were married in families where all the necessities of life were already available. In the case of Hazrat Fatima, these facilities were not available and the Holy Prophet has to arrange for them. According to the teaching of Islam, all the expenses of marriage were to be bound by the bridegroom. The Holy Prophet (PBUH) asked Hazrat Ali to first arrange a separate house for the new family and the money required for meeting other expenses. It may be mentioned here that Hazrat Ali was brought up by the Holy Prophet (PBUH) himself and he could easily meet the expenses of his wedding. But as He had to set a practical example for the whole Ummah, he arranged this marriage strictly by the teachings of Islam (Amatullah, 2006).

In the Holy Quran it is requested to all Muslims: "And give women (on marriage) their dower (Mahr) as an unconditional present; however, on the off chance that they, of their 
great joy, transmit some portion of it to you, take it and appreciate it with right happiness" (AnNisa':4; Amatullah, 2006). This implies that Mahr or dowry isn't so much carefully requested and it isn't mandatory to pay cash or anything to women also, in Islam dowry is alluded to as a blessing. In Pakistan, numerous cultures comprising of the system to request dowry from the girl family are rather than the Islamic conviction. Dowry is absolutely a social standard set by the people, not by religion. Prophet Mohammad (PBUH) stated, "The best of the marriages is one which is least troublesome in the monetary sense to the groups of the lady and the husband to be" (Amatullah, 2006). Even though the dowry has never been recommended by Islam, it is available and women are enduring as a reason for aggressive behavior at home.

Dowry gives no advantage to society. It is demonstrated as social wickedness. It leads toward advancing numerous contentions, squabbles, and ravenousness in the development. In love and organize marriage both taught and unskilled people are rehearsing the dowry system in the general public of Pakistan. The public is not in the courtesy of this system. A study "Forgotten-Dowry- A Socially endorsed form of violence in Pakistan" in 2009, indicates that several thousand cases of bride-burning have been reported in Pakistan. The Ansar Burney Trust International says that in some cases, accidents are engineered (such as tampering with a kitchen stove to cause the victim's death) or the victims are set ablaze, and the attack is disguised as an accident or as suicide. According to an Amnesty International report in 1999, though 1,600 "bride-burning" cases were reported, only sixty were prosecuted and just two resulted in a conviction. That very study also unveiled that a growing number of girls have started staying unmarried in Pakistan as parents don't have enough money to meet the 'demands' of the groom's family. The custom for an increasingly elaborate dowry is set by the people who do not even need a dowry from the girls to 'run their homes or 'support' the grooms in any way. Certain factors ensure the continuity of the practice of dowry, such as:

- It is considered an incentive to lure a more suitable match.

- It is submission to the demand of a perceived suitable match.

- It is used as an excuse for denial of inheritance to women (the expenses on dowry and wedding are unilaterally decided by the men of the family as transfer of inheritance by other means).

- It is considered a good support mechanism to help the new couple so that they get a convenient start in practical life.

- It has become a socially enforced practice that is followed and executed 'with a smile'; notwithstanding how painful it could be to the family.

Obligatory dowery (jahaz) takes a heavy toll on the family of the bride. "The actors in dowry violence are men and women who are participants in local, regional or national cultures, in religious and social-traditional and yet current and contemporary normative orders that are in the process of being constantly tested and modified" (Anderson, 2003). Dowry demand, dowry acceptance, dowry offering, and lavish wedding are not only proxy indicators of the deteriorating mental health and moral standards of our society but the payment of dowry is a rejection of Islamic values and a violation of the 1976 Dowry and 
Bridal Gift (Restriction) Act as well. This can appear an alarm to only those who have respect for the law and believe in rule of law.

\section{Material and Methods}

Qualitative data was collected through the self-constructed interviews guide. Respondents belonged to lower, middle, and upper-class joint families; mostly were illiterate or less-educated and some of them were well educated; married, unmarried and about to get married from urban and rural areas of Lahore (Johar City, Harbanspura, DHA and Chauburji), Arifwala, Chichawatni, Islamabad and Jhang. Respondents were aged from 18 to 45 years. By using the purposive sampling method, thirty-one interviews were conducted both from males and females. The interviews were transcribed and thematic analysis was done to bring out the emerging themes and major themes.

Other than demographic information (age, education, years of marital life, family status, family system, profession); data were collected to explore the perceptions about dowry, causes of the dowry, and how it affects women's rights. Views were recorded about males' females' perceptions to find gender differences, their effects on women's rights and autonomy. The experiences of married respondents were recorded about the treatment of in-laws, authorities of females after marriage in their new house.

\section{Results and Discussion}

The age of the respondents was between 18 to 45 years. Six were (18-25) years; four were between (30-40) years and the rest two falls in the (40-45) age bracket. Six respondents were University graduates; one was matriculated and the rests were uneducated. Two participants were sociologists, one was an advocate, one female was Architect from the National College of Arts, one female belonged to the medical field, two were students, four domestic workers were interviewed who were supported their families.

\section{Perceptions about Dowry}

Most of the respondent's views about "dowry is giving wealth, luxuries, furniture, car/bike, property/house, business or cash to groom's family"; "dowry is a set of demand which needs to be full filed before marriage or on day of marriage". Few said that "Dowry is what brides' parents give as a gift to their daughter for her new house". One participant stated, "dowry as a disease with no cure, this disease can be treated a little but cannot eliminate from society". Some view it as a cultural tradition. They didn't consider it as a root cause of women's rights or social problems. They said that "dowry is not something to be demanded but to a choice."

\section{Males' Females' Perspectives}

Male respondents said that "dowry should not be demanded but an option for bride's family if they can afford it but they should give it". In short, they support it with different arguments like it's a culture "it's a general trend which is going on without any stop". 
Female respondents said, "dowry should not be a demand or a necessary thing to give in every wedding". Some female participants explained that "modernization affects dowry the most" in terms of Technology and Price. Gold jewelry is very expensive etc. They said that wedding expenses crossed from single to double of its demands. Few male respondents said, "it a burden on brides' parents". We will not ask for dowry, it will be a choice for brides' parents.

Few participants said, "......not to take any dowry but we might have to give dowry on our sisters/daughters time (furniture, appliances, car, house, and gold) because of society". Only three participants two female and one male said "we will not take or give dowry at all cost".

Few respondents said that "unnecessary trends, luxuries, and demands" is affecting more economically than traditionally and should not be practiced in Islamic society". They further added, "dowry is becoming a part of our wedding ceremonies - a custom in which both sides show off their gifts to bride especially the bride side has to be the winner to bring respect to her bride". The Advocate belongs to Chichawatni said, "dowry is a matter of respect in their sub-culture of Chichawatni and Rural Punjab".

Some respondents said that "throwing out from the house is common if the in-laws are not satisfied with a dowry. So, the parents have to arrange dowry as much as they can. Better the dowry -better the bride will be". In the opinion of two female respondents "dowry is a curse and it a valuation of women based on materialistic things" valuing the women with materialistic things. She further quoted the word "BARRAT" which means "to get rid of lowvalue able things or a trouble". One young working woman responded "If we see the diseases like Cancer, AIDS and many more like that, Dowry is much dangerous disease from all of them. Like someone has diabetes and this disease harm the patient's body having diabetes internally".

The medical professional said "As far as I am concerned, I denied or against the dowry system. There is no importance of such old traditions and customs nowadays and it is useless or baseless to support or encourage such trends that are of no productive conc. These traditions were introduced in old times by our old age people or our parents, they were less educated and were not aware of its consequences but for now, people are changing their minds and protesting against such old rough nasty customs". The perceptions about dowry among respondents were very versatile and diverse based on experiences.

\section{Impacts of Dowry}

\section{Social}

Dowry is a social burden on the bride and her family. A respondent from rural background said that "social pressure is one of the major causes of high demands from groom's family despite the fact many people do not demand dowry but society makes them do it or on other hand mostly parents from bride side couldn't afford dowry but they still do because of social pressure".

Other respondents considered "dowry as character-defining element after marriage because in rural background women got beaten the most because of dowry and blamed as characterless" as a result of violence. "Most crucial relations for women started at the time of 
marriage when two families of different thoughts come together and make a new relationship where women start her new life with new relations so dowry plays an important indicator for women importance in her in-laws. The valuation of women's own self in the name of dowry in a patriarchal society is not a new thing" said a social activist where over-evaluation of a groom and devaluation of a woman is common.

Two respondents said that "after marriage women, life depends on her dowry". Three respondents said that "late Marriages, divorces, and disturbed marriages" are getting increased by the high demands of society in terms of dowry. Those who faced hardships in their life at the weddings, they narrated real-life stories about how dowry affects a women's gender. Dowry is considered an important part of marriage in our society.

\section{Financial}

Dowry is a financial burden. One participant said that for financial arrangements of loans and services "they visited many banks, companies, shops giving loans and installments for dowry". Insurance companies in Pakistan introduced policies in the Name of "Child education and Marriage Plan". This financial burden leads parents and guardians towards loans and selling properties. One mother added, "we have to do unwantedly in any way either takes loan". One social activist participant said "a father worked as a guard in a bank sell everything along with his kidney and died in this process"; "Those who took loans for dowry spent rest of their lives to pay back it."

One participant informed her own experience that in-laws are demanding a new model expensive car as she belongs to a wealthy family. So much so in-laws asked her to leave their job and be a housewife which affects her professional carrier. Due to modernization, new trends and fashions are introduced in daily life with innovative ideas such as appliances, luxuries, jewelry, and vehicles. This is increasing the unnecessary burden. Almost half of the participants said "dowry is a major barrier in weddings that cause a delay in marriages, especially for a female. When women get married late, more dowries are demanded by the groom's family." A long time is required for lavish dowry."

\section{Psychological}

Dowry demands effects not only females but also their parents/guardians psychologically who are unable to meet dowry demands. It leads them towards tensions, depression, anxiety, and constant threat. A bride from a medical professional informed, "it's a cause of creating illness, depression, anxiety in young girls that lead them to stay at their homes for lifetimes and damage their souls, kill their feelings and restrict or bound them to begin a happy married life".

Some respondents from a low-class family who were going to marry said "we as a daughter are seeing tension and hard comes to our parents having due to dowry demands. We are constantly in depression and feeling our self's a curse on our families". Furthermore, they said taught "we have seen our parents' collecting things for our marriage and cutting down their lifestyle expenses to save for future wedding". 
After marriage, dissatisfaction or greed of in-laws flares up the unwanted situations. Constant teasing conversations increases tensions, de-shapes the relationships, convert good things into bad ones which resulted in conflicting situations and domestic abuse. The study of Ali and Bustamante-Gavino indicates dowry - a reason for verbal and physical abuse inflicted by in-laws in $9.5 \%$ and $13 \%$ of cases, respectively.

\section{Why dowry is essential for Marriage}

One participant said, "it helps to get the importance of females". Some said "it's a tradition".... "We can't take the risk so dowry is an essential part of their family wedding or their weddings". One participant said, "I am not ready by myself to take dowry but I don't want to take the risk for my sister and daughter, have to do something". Most female participants were informed that their in-laws will make their lives miserable; full of taunt if they failed to arrange enough dowries. One participant informed "educated girls from middle-class face problems in marriage. Parents are forced to give dowry to their daughters so that they can live happy marital life without any inferiority complex".

Few females and one male participant highlighted that "even after they got dowry, in-laws and husband blackmail bride and her parents in term of loans, the demand of the house, business share, car or money. In-laws threaten parents by violence, anger, and warnings". Dowry affects women character by her in-laws. A participant said that "we have seen people blaming their wives', daughters-in-law on their character to get rid of her or to fulfill their anger of not giving them enough dowries".

\section{Competition among Brides to gain more Respect}

Two males and one female participant informed that "dowry can never secure a bride future because there is always a competition between brides' within a family. For example, if there are four brides in one house, the most favorable are those who bring more dowry or modern items. This competition leads to never-ending expectations which lead towards constant insecurity and lifetime torture. Furthermore "in-laws treated as disrespectful creature especially women of the working class and low-income class". Disrespect creates negative feelings like an inferiority complex.

\section{Shield against Domestic Violence}

Almost all the participants indicate dowry work as a shield against domestic violence, verbal and physical abuse. One participant said, "in his life, he has seen many women got beaten or mistreated by her in-laws due to less dowry or insufficient dowry". Three respondents narrated that the cause of violence in women's life was the "dowry". They belonged to lower-middle-class families who got dowry at the time of marriage but even after that in-law criticized daughter-in-law because of fewer dowries. In another case, the violence began when the family of the bride didn't give the required dowry to her in-laws. Participants quoted many reported incidences about "Brides beaten to death by husband or in-laws due to dowry". Brides subjected to violence include intensive beating, physical torture, burn alive, and even rapes by husband or in-laws, relatives. 


\section{Dowry as Preventive Remedy to Avoid Divorce}

Participants informed that heavy dowry saves brides from divorce. They blamed little dowry for divorces "in case of little dower, in-laws sent back to parents' house". Marital life affects badly as day-to-day quarrels or demands make relationships nasty between husband and wife and with in-laws. "Quarrelsome life eventually leads towards separation or divorce".

\section{How dowry affects women rights and Autonomy}

Participants views on women rights:

\section{Rights to Education}

Most of the middle class and lower-middle-class parents save the amount for marriage despite investing that amount on their daughters' education; this is how it affects professional growth. Female and male respondents told that "women development is embraced with education, skills development, and professional carrier's development to personal development". A male participant said, "educated and personally/professionally developed women manage things in a better way".

\section{Property Rights}

Two male participants said "When a dowry is considered as gifts to bride and groom for their new life in our society what parents or families do is they considered dowry as their property right. But we have seen dowry is to satisfy the groom's family rather than for their daughter. Everything she brings with her she cannot own them in her husband's house". Most parents and participants mixed up the dowry system with the property rights of their daughters. They think that the things (jewelry, cash, wedding expense land, house, car, etc) they are giving to their daughters are their share in parents' property. They expect their daughters to not ask or demand. It's a violation of their rights.

\section{Right of acceptance}

Female participants expressed the perception that "in the $21^{\text {st }}$ century when a girl is born, parents/society start taking them as a burden or curse. They ignored the value and status; women are already given in Islam. It's a general practice in our society". A female social activist and culturist said "Giving dowry is increasing the value of their daughter because women are considered as devalued in her society their acceptance is always a question in their life".

\section{Gender Discrimination}

According to female participants "women are treated inhumanly by their husbands or elder males/females in ways of domestic violence, honor killing forced marriages, etc. most of the cases we see around us because of dowry". Few participants informed about "Gender discrimination started when they were born. Sons are always on priority in terms of education, food, freedom, extracurricular activities, and sports and even in social life they felt 
discriminated". From birth, daughters are treated as a guest and given fewer opportunities in their life than sons as parents have started to save for their dowry.

\section{Right in decision making}

Women's decisions are influenced by male family members, society, and in-laws. They are not allowed to ask for their basic right in a wedding that is "Haq Mehar that is purely a decision of women but instead her parents or groom's family chose it for them". "Male's decisions are considered the final one" an educated respondent from Lahore and another highly professional female from the medical field said, "Males do what they feel right. They never discuss or take opinion from a highly qualified woman".

\section{Discussion}

Dowry a social evil is still controversial in our society. Parents viewed dowry as a token or shield of happy marital life. They arranged with good intentions for a better and more secure future for their daughters (Kishwar, 1986). Unfortunately, dowry never works as a protective shield as most of the respondents said. It has become a curse or greed or a source of status lifting machines. Fewer low-quality products of dowry become the cause of violence, physical or mental torture, stress and tensions, and domestic abuse (Ali, Mogren, \& Krantz, 2011).

The increasing figures of brides' deaths, burning, and suicide cases are indicating the alarming situations. It's time to take practical steps to handle the situations (Naveed \& Persson, 2005; Naveed \& Persson, 2010). Awareness to follow the teachings of Islam (Amatullah, 2006), the implementation of Laws in the true spirit, collaborative efforts at all levels with male support may protect half population from the negative consequences of dowry. Empowerment of women through education uplifts the status of women in society (Bates, Schuler, Islam, \& Islam, 2004; Sharma, Harish, Sharma, \& Vij, 2002; Garger, 2007; Kishwar, 1986).

Consistent efforts will bring a change in the mindsets by increasing the educational level among youth. Awareness about dowry issues and women empowerment gear up the process of change and minimize the negative consequences of such customs. Mobilizations of young boys and girls against dowry vibrate society towards healthy social life. Realization of the sensitivity of the dowry issues and crimes under its umbrella will help to identify an acceptable solution that is how to spend a dignified life, free from unwanted social pressures.

Discussion forums between bride and groom families are a good platform "compromise marriage without giving and take", adoption of simplicity, etc. The active role of males plays a key role in strengthening women's rights as well as encouraging women to enable them to take charge of their lives rather than live a life of hapless dependence (Kishwar, 2005).

\section{Conclusion}

The study unveils the factual realities, perceptions, and opinions of the general public who were aware and accepted the negative aspects of the dowry system. Dowry is an unacceptable way of progress and development. One who intended to go up on the status 
ladder now has to adopt other expected and accepted measures morally and ethically available in society. Education (formal, religious, technical, etc.) opens up the doors, shows the right directions to choose the right path to earn respectably. Thinking and decisionmaking in a positive way are essential for living a prosperous happy life. Simplicity is the key to nipping the dowry evil in the bud. It resolves all issues very easily as study respondents expressed. Dowry is not a guarantee for a happy life. With the increasing awareness and knowledge, the social fabric is under a change in every society. There are now legal covers that existed for the protection.

The study concluded heavy dowry especially in terms of furniture, electronics, kitchenware, car, furnished houses, and cash highly associated with women's married life, development, and rights. General people's perception showed that dowry is no longer remained a custom or tradition in Asian countries. Realization of seriousness and acceptance of the issues at all levels needs the support of public and private masses. Education and practices are the keys. The factual situations, ground realities, circumstances, causes, and their impacts on marriages and relationships among the middle and poor class gear up the patterns of thinking and bring changes in society. Although changing mindset process is slow but is growing and spreading especially in literate classes. It is just a trend to show off wealth. People who follow it as a symbol of respect for parents/family and the women need to understand the severity of the issue. Constant and persistent efforts are required to get rid of this evil. 


\section{References}

Ali, T.S. and Bustamante-Gavino, I. (2007). Prevalence of and reasons for domestic violence among women from low socioeconomic communities of Karachi. Eastern Mediterranean Health Journal, 13, 1417-1426.

Ali, T.S., Mogren, I. and Krantz, G. (2011). Intimate partner violence and mental health effects: A population-based study among married women in Karachi, Pakistan. International Journal of Behavioral Medicine, 20, 131- 139.

Anderson, Siwan (2000). The economics of dowry payments in Pakistan, Mimeo, Tilburg University Press, Center for Economic Research.

Anderson, S. (2007). The economics of dowry and bride price. Journal of Economic Perspectives, 21, 151-174

Asian Human Rights Commission (2014). PAKISTAN: The social injustice behind the practice of dowry-when greed dictates society. Asian Human Rights Commission

Bates, L.M., Schuler, S.R., Islam, F. and Islam, K. (2004). Socioeconomic factors and processes associated with domestic violence in rural Bangladesh. International Family Planning Perspectives, 30, 190-199.

Diamond-Smith, N., Luke, N. and Mcgarvey, S. (2008) Too many girls, too much dowry: Son preference and daughter aversion in rural Tamil Nadu, India. Culture, Health \& Sexuality, 10, 697-708

Garger, I. (2007). The dowry dilemma. Psychology Today.

Ibraz, T. S., Fatima, A., \& Aziz, N. (1993). Uneducated and Unhealthy: The Plight of Women in Pakistan, The Pakistan Development Review, 32 (4), 905-915.

Imtiaz, Subhani, Muhammad; Sarwat, Afza (2018). To estimate an equation explaining the determinants of Dowry, RePEc:pra:mprapa:21365

Juliette, Terzieff (2002, October 27). Pakistan's Fiery Shame: Women Die in Stove Deaths" We News,

Kishwar, M. P. (1986). Dowry—To ensure her happiness or to disinherit her? Manushi, India.

Kishwar, M. P. (2005). Strategies for Combating the Culture of Dowry and Domestic Violence in India, Manushi,

Miller, B. D. (1984). "Daughter neglect, women's work, and marriage: Pakistan and Bangladesh compared. Medical Anthropology. 8 (2): 109-126

Momoe Makino (2019). Marriage, dowry, and women's status in rural Punjab, Pakistan. Journal of Population Economics, 32, 769-797 
Naved, R.T., and Persson, L.A. (2005). Factors associated with spousal physical violence against women in Bangladesh. Studies in Family Planning, 36, 289-300.

Naved, R.T., \& Persson, L.A. (2010). Dowry and spousal physical violence against women in Bangladesh. Journal of Family Issues, 31, 830-856.

Niaz, U. (2004). Women's mental health in Pakistan. World Psychiatry, 3 (1), 60-2.

Rao, V. (1993). Dowry inflation in Rural India: A statistical investigation. Population Studies, $47,283-293$

Shah, K. (1960). Attitudes of Pakistani students toward family life. Marriage and Family Living, 22 (2), 156-161

Sharma, B.R., Harish, D., Sharma, V., and Vij, K. (2002) Kitchen accidents vis-a-vis dowry deaths. Burns: Journal of the International Society for Burn Injuries, 28, 250- 253.

Subhani, D., Imtiaz, M., \& Afza, S. (2009). To estimate an equation explaining the determinants of Dowry. MePRC Journal. University of Munich; Germany.

Tazeen, S. Ali., Gunnhildur, Á., \& Asli, K. (2013). Dowry practices and their negative consequences from a female perspective in Karachi, Pakistan -A qualitative study, 5 (7A4), 84-91

Yasmeen, S. (1999). Islamization and democratization in Pakistan: Implications for women and religious minorities", South Asia Journal of South Asian Studies, 22(s1), 183-195. 